Braga, O. ; Smythe, G.A. ; Schäfer, A.I. ; Feitz, A.J. (2005) Steroid estrogens in ocean sediments, Chemosphere, 61, 827-833.

doi:10.1016/j.chemosphere.2005.04.053

\section{Steroid estrogens in ocean sediments}

A.J. Feitz ${ }^{* a}$, O. Braga ${ }^{\text {b }}$ A.I. Schäfer ${ }^{c}$ and G.A. Smythe ${ }^{b}$

${ }^{a}$ Centre for Water and Waste Technology, School of Civil and Environmental Engineering, University of New South Wales, Sydney, NSW, 2052, Australia.

bBioanalytical Mass Spectrometry Facility, Faculty of Medicine, University of New South Wales, Sydney, NSW, 2052, Australia.

'Civil, Mining and Environmental Engineering, University of Wollongong, NSW, 2522, Australia.

\section{Submitted to Chemosphere}

January 2005

Feitz: Tel: +61 29385 5082,Fax + 6129313 8624, E-mail: andrew.feitz@unsw.edu.au

\section{Abstract}

Ocean sediment samples were taken adjacent and $7 \mathrm{~km}$ from a deep ocean outfall (average depth $80 \mathrm{~m}$ ), the discharge point of an enhanced primary sewage treatment plant. All samples contained steroid estrogens at nanogram per gram levels with higher concentrations at the $7 \mathrm{~km}$ sampling site. The concentration of estrone ranged from $(0.16-1.17 \mathrm{ng} / \mathrm{g}), 17 \beta$-estradiol $(0.22-2.48 \mathrm{ng} / \mathrm{g})$ and the synthetic $17 \alpha$ ethinylestradiol $(<0.1-0.5 \mathrm{ng} / \mathrm{g})$. The values detected correspond with estimates based on the proportion of estrogens sorbed to particles in the effluent and the expected proportion of sewage origin particles in the ocean sediments. The results suggest that estrogens associated with the particulate fraction aggregate on contact with high ionic strength seawater and settle to the seafloor after discharge through deep ocean outfalls

Keywords: estrone, estradiol, ethinylestradiol, sediment, wastewater, sewage

\section{Introduction}

Understanding the fate of estrogens in the environment is key to understanding the potential for human released estrogens to induce abnormal reproduction in aquatic environments (Purdom et al., 1994; Desbrow et al., 1998; Routledge et al., 1998). Estrogens have been detected in rivers (Kuch and Ballschmitter, 2001; Snyder et al. 2001; Alder et al., 2001), lakes (Matsui et al., 2000; Shen et al., 2001; Snyder et al., 2004) and marine samples (Atkinson et al., 2003; Tashiro et al., 2003 ) and the primary sources are considered to be from sewage treatment plants and agricultural runoff or discharge (Tashiro et al., 2003; Kolodziej et al., 2004). There is now increasing evidence that estrogens such as estrone (E1), 17 $\beta$-estradiol (E2) and 17 $\alpha$-ethinylestradiol (EE2) are sorbing (7) (Mibu cel., degradation, especially for EE2 under anaerobic conditions, is slow (Ying and Kookana., 2003 Ying et al., 2003; Jürgens et al., 2002). The release and fate of estrogens into the marine environment is little studied but of considerable interest as they appear to be relatively stable and show limited degradation even under aerobic conditions (Ying et al., 2003). Their affect on coral reefs is of particular concern (Atkinson et al., 2003). When estrone concentrations are greater than $300 \mathrm{pg} / \mathrm{L}$, there is the potential of net uptake and potential accumulation in the reef benthos (Atkinson et al., 2003). Estrogens in the coastal marine environment may affect reproductive biology through embryonic development (Hathaway and Black, 1969), attered enzymatic activities (Ghosh and Ray, 1993a; Ghosh and Ray, 1993b) or cellular damage or apoptosis (Wiens et al., 1999; Viarengo et al., 2000). Much more information is required to characterise the presence of human-derived estrogens in marine environments and to determine their potential effects on the marine ecosystem. This paper reports on preliminary measurements of estrogens in ocean sediments.

\section{Materials and Methods}

\subsection{Ocean sediment sampling}

Ocean sediment samples were collected near the discharge point from a large coastal enhanced primary sewage treatment plant (STP). The STP is located in eastern Sydney and services domestic sewage $(75 \%)$ and industrial wastewater $(25 \%)$. It provides enhanced primary treatment (i.e. with $\mathrm{FeCl}_{3}$ addition) for an average flow of $480 \mathrm{ML} /$ day with ultimate disposal by deep ocean discharge (3.6km offshore, average $80 \mathrm{~m}$ deep). A Motor Vessel (MV) Oceanographer was used as a stable platform, from which a "Smith McIntyre" grab (capacity approximately $5 \mathrm{~L}$ ) (Fig 1) was deployed to collect sediment samples. Samples were collected from 2 locations ( 2 samples per location), adjacent to the Malabar deep ocean outfall and approximately $7 \mathrm{~km}$ south of the outfall (Fig. 2). The vessel was manoeuvred to hold its position until the grab had reached the seafloor and a sediment sample was taken. In order to ensure samples are as representative as possible, the angle and speed at which the grab was lowered to the seafloor, was controlled and maintained for all the sub-sites. The grab was lowered to approximately $3 \mathrm{~m}$ above the seafloor and then released to collect the sample. In setting the angle and speed at which the grab is lowered, consideration was given to two things: maximising the volume of the sediment sample retrieved; and minimising the bow wave generated from the grab moving through the water column. This method of controlling (Bloomquist, 1992). The samples were transferred to a $0.5 \mathrm{~L}$ glass bottle and stored at $-20^{\circ} \mathrm{C}$ prior to
analysis. 


\subsection{Standard Preparation}

Estrone $\left(\mathrm{E}_{1}\right)$, estradiol $\left(\mathrm{E}_{2}\right)$, ethinylestradiol $\left(\mathrm{EE}_{2}\right)$, and estrone-2, 4,16,16-d4 $\left(\mathrm{d} 4-\mathrm{E}_{1}\right)$ were obtained from Sigma (Aldrich, Sydney, Australia). The d4- $\mathrm{E}_{1}$ was used as internal standard. Stock solutions of individual non-deutered standards and deutered internal standard were prepared by dissolving known a dissting known ans solutions were obtained by further diluting stock solutions with water to obtain final concentrations of $0.5 \mathrm{pg} / \square 1$ to $500 \mathrm{pg} / \square$. The stock solution of internal standard was further diluted with water to obtain a final concentration of $100 \mathrm{pg} / \square$. Methanol and acetonitrile HPLC grade were obtained from (Ajax Finechem, Sydney, Australia). Other solvents were of analytical grade, and they were used as supplied (Ajax Finechem, Sydney, Australia). Milli-Q water was used for all experimental procedures.

\subsection{Preparation of sediment samples}

Analytes were extracted from the sediment samples using liquid phase extraction (LPE). Prior to sample preparation, internal standard was added. Samples were then frozen with liquid nitrogen and then dried in a vacuum refrigerator for $24 \mathrm{hrs}$ at $-70^{\circ} \mathrm{C}$. The dried pellets were weighed and then dissolved in a mixture of $100 \mathrm{ml}$ acetone/hexane (50:50). The solvent-sample slurry was then sonicated for $30 \mathrm{~min}$ followed by stirring and heating to $80^{\circ} \mathrm{C}$ for an hour in a hot plate. The solventsample mixture was then filtered through Whatman No. 1 glass fibre filter paper (Whatman, Sydney, Australia), the pellet rinsed with a mixture of acetone/hexane (50:50), followed by solven evaporation at $80^{\circ} \mathrm{C}$ in a water bath. The residues were dissolved in water. Analytes were then extracted from water extracted from water si (Supelco, Sydney, Australia). After fitting the SPE cartridge into a 12-Por Visiprep DL Vacuum Manifold (Supelco, Sydney, Australia), the SPE was sequentially conditioned with $2 \times 10 \mathrm{~mL}$ methanol, $1 \times 10 \mathrm{~mL}$ Milli-Q water. Sample loading was achieved by passing standards and water samples through the LC-18 SPE cartridge. After sample loading, cartridges were dried in a vacuum desiccator for 30 to $40 \mathrm{~min}$. Elution of the analytes was achieved by passing $2 \times 5 \mathrm{~mL}$ methanol that was collected in a $10 \mathrm{~mL}$ culture tube with screw cap. The collected solution was dried down under vacuum and reconstituted to $1 \mathrm{~mL}$ with acetone before derivatisation and analysis.

\subsection{Effluent sample preparation and centrifugation}

Before effluent samples were processed, internal standard was added. After the addition of various quantities of $\mathrm{NaCl}$, high-speed centrifugation was used to separate the solids particles from the water. Separation of the solid particles was achieved by centrifuging $2 \mathrm{~L}$ samples at $10,000 \mathrm{rpm}$ for $1 \mathrm{hr}$ at $0^{\circ} \mathrm{C}$. The water layer was removed for further solid phase extraction (see above) before derivatisation and analysis using GC-MS.

\subsection{Sample Derivatisation for GC-MS Analysis}

The derivatisation was carried out using a modified version of the method used by Nakamura et al (2001) for the pentafluorobenzyl-trimethylsilyl derivative. To the acetone extract, $100 \mu \mathrm{L}$ of $10 \%$ aqueous potassium carbonate and $10 \mu \mathrm{L}$ of pentafluorobenzylbromide reagent were added, and were kept at $70^{\circ} \mathrm{C}$ for 1 hour. After cooling, the solvent was reduced to $100 \mathrm{uL}$ under vacuum. $1 \mathrm{~mL}$ of toluene was added, and the organic phase was washed with $0.5 \mathrm{~mL}$ of Milli-Q water. The wate layer was discarded and the toluene layer completely removed under vacuum. $100 \mu \mathrm{L}$ o dhe vial and kept at room temperature for $30 \mathrm{~min}$. Toluene was added to $1 \mathrm{~mL}$ before analyses.

\section{Gas Chromatography Mass Spectrometry Conditions}

All GC-MS analyses were carried out using an Agilent 5890 gas chromatograph interfaced to an Agilent 5989B MS Engine (Agilent Technologies, Ryde, Australia). Chromatographic separations were performed with an HP-5MS capillary column $(30 \mathrm{~m}$ x $0.25 \mathrm{~mm}$ i.d. x $0.25 \mu \mathrm{m}$ film thickness). The $\mathrm{GC}$ oven temperature was programmed at $150^{\circ} \mathrm{C}$ for $1.5 \mathrm{~min}$ and then $36^{\circ} \mathrm{C}$ per minute to $310^{\circ} \mathrm{C}$, final hold $7.0 \mathrm{~min}$. The GC-MS interface heater, the ion source, quadrupole, an injection port temperatures were maintained at $260,240,100$ and $260^{\circ} \mathrm{C}$, respectively. Pulse splitless injection was used with a pulse pressure of $241 \mathrm{kPa}(1.1 \mathrm{~min})$ and purge time delay of 8 $\min$. The MS analyses were performed with an electron-capture negative-ion (ECNI) source, using methane as reagent gas (Ultrapure grade, Matheson Gas Products Inc.) and selected ion monitoring ms per single ion. The injection volume was $1.0 \mu \mathrm{L}$. The standards containing all the estrogens (non-deuterated and deuterated) at accurate defined concentrations were derivatized as described above. Quantification was carried out by calculation of the response factors (RF) based on the area of the non-deuterated and deuterated estrogens standard. These ratios were converted to concentrations using a linear regression equation, which was used to assign the unknown concentrations. Signals for method limit of detection (LOD) and limit of quantification (LOQ) was set at 3- and 6-fold height of noise, respectively

\section{Results and discussion}

Marine sediments taken near the ocean outfall were found to contain all three estrogens (Table 1; Fig. 3). The concentration of estrogens $7 \mathrm{~km}$ from the outfall were often considerably higher than immediately adjacent the outfall (Fig. 3). Previous studies monitoring total organic finer particles at the $7 \mathrm{~km}$ sampling site compared to at the outfall (AWT, 2000). Substantially higher TOC and a greater presence of fine particles was found 3 to $5 \mathrm{~km}$ from the outfall, suggesting that higher concentrations of particles and hence estrogens may be located in this region.

Based on silver enrichment data in marine sediments approximately $1-2 \mathrm{~km}$ from the outfall, it is estimated that sewage particles account for approximately $2 \%$ to the surficial sediment (top $10 \mathrm{~cm}$ ) (Matthai et al., 2002). The majority of particles comprise of natural contributions from settling marine particulate matter and resuspended sediment. Using the $2 \%$ figure as a guide and assuming that there is no desorption of estrogens from the particles on contact with the seawater the estimated concentration in the surficial sediments is close to the measured values (Table 2). It is expected that there will be a large fraction of estrogens attached to fine particles (Holthaus et al., 2002; Holbrook et al., 2004) and such particles are likely to aggregate on contact with higher ionic strength waters and show greater settleability. Indeed, after adding various concentrations of salt to the STP effluent samples to induce aggregation, the concentration of E1 in particular in the aqueous sample (i.e. without pellet) decreased markedly without increasing salt concentration (Fig. 4). EE2 was not detected in any of the centrifuged liquid samples.

These preliminary results suggest that estrogens attached to particles in the effluent and, on contact with higher ionic strength seawater, are aggregating and settling to the sea floor. As the measured concentration is similar to the estimated concentration in the marine sediments suggests that the degadaion in the sedlments is slow. The mean $1-2 \mathrm{~km}$ fom the outfll is 0.23 (a) 0.23 $\mathrm{g} / \mathrm{m}^{2} / \mathrm{d}$ (Matthai et al., 2002), which is in the range where sulphate reduction and oxic respiration are likely to be equally important in oxidizing organic matter (Canfield, 1989). Fe and $\mathrm{Mn}$ porewater profile for marine sediments samples taken near the outfall indicate that near the sediment-water interface there is a thin oxic layer but at depths greater than $1-2 \mathrm{~cm}$ in the sediments the presence of elevated dissolved phase $\mathrm{Mn}$ and Fe indicates suboxic to anoxic organic matter reduction (Matthai et al., 1998). Anoxic conditions in marine sediments, in comparison to aerobic conditions, are not conductive to degradation of estrogens and the half-lives for E2 and EE2 biodegradation are greater than 70 days (Ying and Kookana, 2003).

The poor removal of estrogens during primary clarification is well known (Holbrook et al., 2004; Ternes et al., 1999; Anderson et al., 2003). With effectively no removal of E1 and E2 during 
treatment at the STP plant (Braga et al., 2005), it is important to consider the potential impacts of such a large load of estrogens on the receiving environment. The high levels of dilution obtained during ocean disposal may prove sufficient for the prevention of endocrine effects in marine animals, although picomolar concentrations have been shown to affect the development of aquatic organisms (Routledge et al., 1998; Schoenmakers et al., 1981; Harries et al., 1997). Discharges into large bays or harbours where flushing is limited could prove problematic (Atkinson et al., 2003). The presence of trace levels of estrogens in marine sediments needs to be considered in the context Tha presence of trace levels of est that estroge likely to be found in the sediments (e.g. PAHs and organochlorines (Leeming et al., 1991)). Ther are almost certainly other contaminants in the marine sediments, present at higher concentrations, but with lower estrogenic activity in the sediments. Further studies are required to determine the extent that estrogens present at nanogram per gram concentrations in the sediments affect marine invertebrates, the base of the aquatic food chain, and whether the presence of estrogens poses a risk to ecosystem function.

\section{Conclusions}

Steroid estrogens were found in deep ocean sediment samples at nanogram per gram concentrations. The presence of the synthetic $17 \alpha$-ethinylestradiol in the sediments confirms that the estrogens (at least 17 $\alpha$-ethinylestradiol) are of human origin. While there are likely to be other compounds that exhibit estrogenic behaviour in the sediments, steroid estrogens have high estrogenic activity and their presence may affect the sediment ecology. Further studies are needed estrogenic activity and their presence may affect the sediment ecology. Further studies are needed
to determine whether estrogens, at low concentrations detected, affect the development of marine invertebrates and whether there is potential for estrogen bioaccumulation in the marine environment.

\section{Acknowledgements}

Scholarship and financial support from BMSF and the UNSW Faculty of Engineering for Olga Braga is gratefully acknowledged, as is the assistance with the sediment sampling from Pete Morrall and Mal Finnan (Sydney Water Corporation) and Paul Dixon (Sydney Water Corporation) with the effluent sampling. Many thanks to Steve Biddulph for organising the sediment sampling and providing details on the sampling equipment. Comments provided by David L. Sedlak are also greatly appreciated. Matthias Bonerz and Thomas Ternes (ESWE Wiesbaden) are acknowledged fo thank Mr Ray Williams for the generous provision of mass spectrometer equipment.

\section{References}

Alder, P., Steger-Hartmann T., Kalbfus. W., 2001. Distribution of natural and synthetic estrogenic steroid hormones in water samples from Southern and Middle Germany. Acta Hydrochim. Hydrobiol. 29, 227-241.

Andersen, H., Siegrist, H., Halling-Sørensen B., Ternes, T.A., 2003. Fate of estrogens in a municipal sewage treatment plant. Environ. Sci. Technol. 37, 4021-4026.

Atkinson, S., Atkinson M.J., Tarrant, A.M., 2003. Estrogens from sewage in coastal marine environments, Environ. Health Persp. 111, 531-535.

Australian Water Technologies, Sydney Water, NSW Environment Protection Authority, 2000. Offshore Sediment Program 2000: Report - Final. AWT, Sydney.

Blomquist, S., 1992. Geochemistry of Coastal Baltic Sediments: Processes and Sampling Procedures. Ph.D. Thesis. Department of Geology and Geochemistry, University of Stockholm

Braga, O., Smythe, G.A., Schäfer, A.I., Feitz, A.J., 2005. Fate of steroid estrogens in Australian inland and coastal wastewater treatment plants, Environ. Sci. Technol. (submitted).

Canfield, D.E., 1989. Sulfate reduction and oxic respiration in marine sediments: implications for organic carbon preservation in euxinic environments. Deep Sea Res. 36, 121-138.

de Alda, M.J.L., Gil, A., Paz E., Barcelo, D., 2002. Occurrence and analysis of estrogens and progestogens in river sediments by liquid chromatography-electrospray-mass spectrometry. Analyst 127, 1299-1304.

Desbrow, C., Routledge, E.J., Brighty, G.C., Sumpter J.P., Waldock, M., 1998. Identification of estrogenic chemicals in STW effluent: 1. Chemical fractionation and in vitro biological screening. Environ. Sci. Technol. 32, 1549-1557.

Ghosh, D., Ray, A.K., 1993a. 17ß-hydroxysteroid dehydrogenase activity of ovary and hepatopancreas of freshwater prawn, Macrobrachium rosenbergii, in relation to ovarian condition and estrogen treatment. Gen. Comp. Endocrinol. 89, 248-254.

Ghosh, D., Ray, A.K., 1993b. Subcelluar action of estradiol-17ß in a freshwater prawn, Macrobrachium rosenbergii, Gen. Comp. Endocrinol. 90, 273-281.

Harries, J.E., Sheahan, D.A., Jobling, S., Matthiessen, P., Neall, P., Sumpter, J.P., Tylor, T., Zaman, N., 1997. Estrogenic activity in five United Kingdom rivers detected by measurements of vitellogenins in caged male trout. Environ. Toxicol. Chem. 16, 534-542.

Hathaway, R.R., Black, R.E., 1969. Interconversions of estrogen and related developmental effects in sand dollar egg. Gen. Comp. Endocrinol. 12, 1-11.

Holbrook, R.D., Love, N.G., Novak, J.T., 2004. Investigation of sorption behavior between pyren and colloidal organic carbon from activated sludge processes Environ. Sci. Technol. 38 , 987-4994

Holthaus, K.I.E., Johnson, A.C., Jürgens, M.D., Williams, R.J., Smith J.J.L., Carter J.E., 2002. The potential for estradiol and ethinylestradiol to sorb to suspended and bed sediments in some English rivers. Environ. Toxicol. Chem. 21, 2526-2535.

Jürgens, M.D., Holthaus, K.I.E., Johnson, A.C., Smith, J.J.L., Hetheridge M., Williams, R.J., 2002. The potential for estradiol and ethinylestradiol degradation in English rivers. Environ. Toxicol. Chem. 21, 480-488. 
Braga, O. ; Smythe, G.A. ; Schäfer, A.I. ; Feitz, A.J. (2005) Steroid estrogens in ocean sediments, Chemosphere, 61, 827-833.

Kolodziej, E.P., Harter T., Sedlak. D.L., 2004, Dairy wastewater, aquaculture, and spawning fish as sources of steroid hormones in the aquatic environment. Environ. Sci. Technol. 38, 63776384.

Kuch H.M., Ballschmitter K., 2001. Determination of endocrine-disrupting phenolic compounds and estrogens in surface and drinking water by HRGC-(NCI)-MS in the picogram per liter range. Environ. Sci. Technol. 35, 3201-3206.

Leeming, R., Rayner, M., Latham, V., Nichols, P., 1991. Characterisation of urban sewage effluent in Sydney's coastal waters using specific organic markers - I, CSIRO Marine Laboratories, Hobart, Australia.

Matsui, S., Takigami, H., Matsuda, T., Taniguchi, N., Adachi, J., Kawami H., Shimizu, Y., 2000. Estrogen and estrogen mimics contamination in water and the role of sewage treatment. Wat. Sci. Technol. 42, 173-179.

Mattahi, C., Birch, G.F., Bickford, G.P., 2002. Anthropogenic trace metals in sediment and settling particulate matter on a high-energy continental shelf (Sydney, Australia). Mar. Environ. Res. $54,99-127$

Mattahi, C., Birch, G.F., Szymczak, R., 1998. Suboxic early diagenetic processes in surficial sediments near a deepwater ocean outfall, Sydney, Australia. J. Geochem. Explor. 64, 1-17.

Mibu, K., Wada, J., Okayasu, Y., Tsumori, J., Komori, K., Tanaka, H., Li, J.H., Sasaki M., Sato. C., 2004. Distribution of estrogen, nonylphenol and its derivatives in the sediments of a shallow lake. Wat. Sci. Technol. 50, 173-179.

Nakamura, S., Sian, T.H., Daishima, S.J., 2001. Determination of estrogens in river water by gas chromatography-negative-ion chemical-ionization mass spectrometry. J. Chromatography A, $919,275-282$.

Peck, M., Gibson, R.W., Kortenkamp A., Hill, E.M., 2004. Sediments are major sinks of steroidal estrogens in two United Kingdom rivers. Environ. Toxicol. Chem. 23, 945-952.

Purdom, C.E., Hardiman, P.A., Bye, V.J., Eno, N.C., Tyler C., Sumpter. J.P., 1994 Estrogenic effects of effluents from sewage treatment works. Chem. Ecol. 9, 275-285.

Routledge, E.J., Sheahan, D., Desbrow, C., Brighty, G.C., Waldock M., Sumpter, J.P., 1998. Identification of estrogenic chemicals in STW effluent: 2. In vivo responses in trout and roach. Environ. Sci. Technol. 32, 1559-1565.

Schoenmakers, H.J.N., van Boheman C.G., Dieleman. S.J., 1981. Effects of oestradiol-17 $\beta$ on the ovaries of the starfish Asterias rubens. Develop. Growth Differ. 23, 125-135.

Shen, J.H., Gutendorf, B., Vahl, H.H., Shen L., Westendorf, J., 2001. Toxicological profile of pollutants in surface water from an area in Taihu Lake, Yangtze Delta, Toxicology 166, 7178.

Snyder, E.M., Snyder, S.A., Kelly, K.L., Gross, T.S., Villeneuve, D.L., Fitzgerald, S.D., Villalobos S.A., Giesy, J.P., 2004. Reproductive responses of common carp (Cyprinus carpio) exposed in cages to influent of the Las Vegas Wash in Lake Mead, Nevada, from late winter to early spring. Environ. Sci. Technol. 38, 6385-6395.

Snyder, S.A., Villeneuve, D.L., Synder, E.M., Giesy. J.P., 2001. Identification and quantification of estrogen receptor agonists in wastewater effluents. Environ. Sci. Technol. 35, 3620-3625.

Sydney Water Corporation, 2002. Environmental Indicators Compliance Report 2002. http://www.sydneywater.com.au/html/environment/eicr/eicrpdfs.html, accessed Feb 2004.

Tashiro, Y., Takemura, A., Fujii, H., Takahira K., Nakanishi. Y., 2003. Livestock wastes as a source of estrogens and their effects on wildlife of Manko tidal flat, Okinawa. Mar. Pollut. Bull. 47, 143-147.
Ternes, T.A., Stumpf, M., Mueller, J., Haberer, K., Wilken, R.-D., Servos, M. Behavior and occurance of oestrogens in municipal sewage treatment plants - I. Investigations in Germany, Canada and Brazil. Sci. Tot. Environ. 225, 81-90.

Thomas, K.V., Balaam, J., Hurst, M., Nedyalkova Z., Mekenyan. O., 2004. Potency and characterization of estrogen-receptor agonists in united kingdom estuarine sediments. Environ. Toxicol. Chem. 23, 471-479.

Thomas, K.V., Hurst, M.R., Matthiessen P., Waldock. M.J., 2001. Characterization of estrogenic compounds in water samples collected from United Kingdom estuaries. Environ. Toxicol. Chem. 20, 2165-2170.

Viarengo, A., Marro, A., Marchi, B., Burlando, B., 2000. Single and combined effects of heavy metals and hormones on lysosomes of haemolymph cells from the mussel Mytilus galloprovincialis. Mar. Biol. 137, 907-912.

Wiens, M., Seack, J., Koziol, C., Hassanein, H.M.A., Steffen, R., Korzhev, M., Schroder, H.C. Muller, W.E.G., 1999. 17ß-estradiol-dependent regulation of chaperone expression and telomerase activity in the marine sponge Geodia cydonium. Mar. Biol. 133, 1-10.

Williams, R.J., Johnson, A.C., Smith J.J.L., Kanda, R., 2003. Steroid estrogens profiles along river stretches arising from sewage treatment works discharges. Environ. Sci. Technol. 37, 17441750 .

Ying G.G., Kookana, R.S., 2003. Degradation of five selected endocrine disrupting chemicals in seawater and marine sediments. Environ. Sci. Technol. 37, 1256-1260.

Ying, G.G., Kookana, R.S., Dillon, P., 2003. Sorption and degradation of selected five endocrine disrupting chemicals in aquifer material. Wat. Res. 37, 3785-3791. 
Braga, O. : Smythe, G.A. ; Schäfer, A.I. ; Feitz, A.J. (2005) Steroid estrogens in ocean sediments, Chemosphere, 61, 827-833. doi:10.1016/j chemosphere 2005.04.053

Figure 1: Smith McIntyre grab sampler

Figure 2: Sediment sample collection locations

Figure 3. Concentration of estrogens in sediment samples taken $0 \mathrm{~km}$ and $7 \mathrm{~km}$ from the deep ocean outfall. Error bars indicate standard error of the mean.

Figure 4. Estrogen content in the separated liquid sample after the addition of $\mathrm{NaCl}$ to STP effluent samples and high speed centrifugation. EE2 was not detected in any liquid samples after centrifugation.

\section{Table caption}

Table 1. Measured and expected concentration of estrogens assuming no desorption from effluent sewage particles upon ocean disposal.

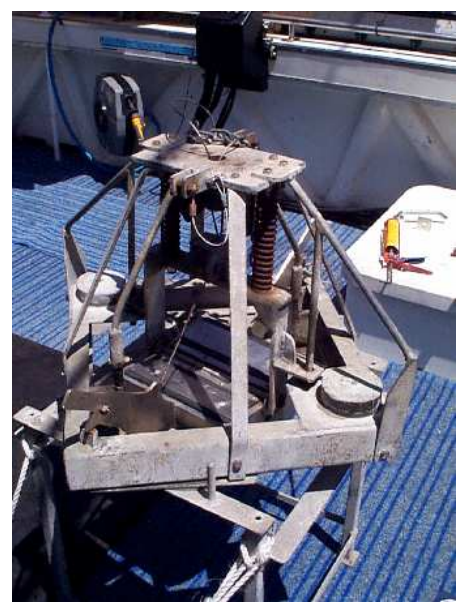


Braga, O. ; Smythe, G.A. ; Schäfer, A.I. ; Feitz, A.J. (2005) Steroid estrogens in ocean sediments, Chemosphere, 61, 827-833. doi:10.1016/j.chemosphere.2005.04.053
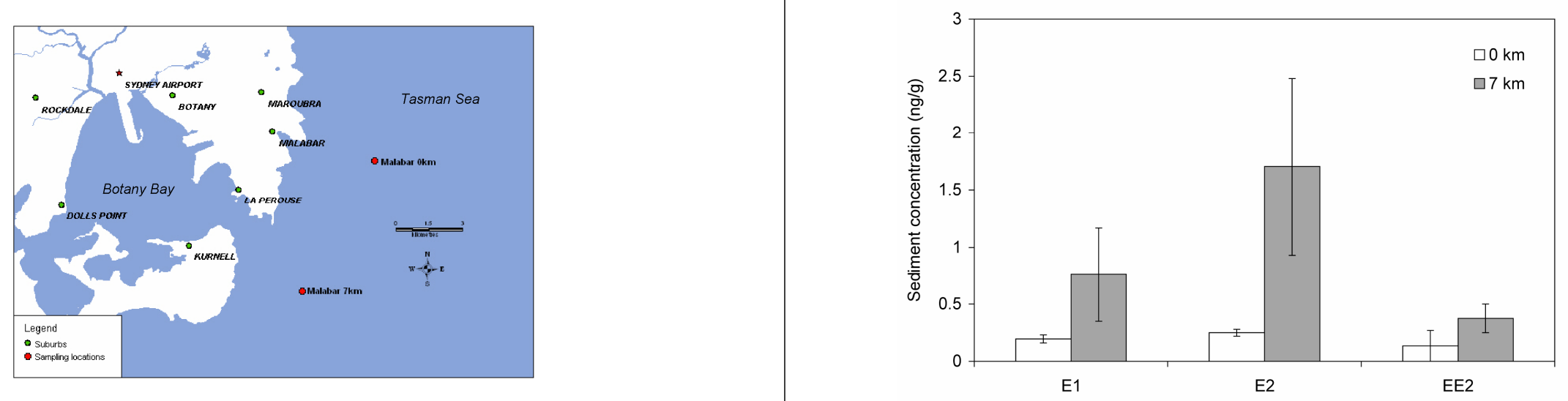
Braga, O. ; Smythe, G.A. ; Schäfer, A.I. ; Feitz, A.J. (2005) Steroid estrogens in ocean sediments, Chemosphere, 61, 827-833. doi:10.1016/j.chemosphere.2005.04.053

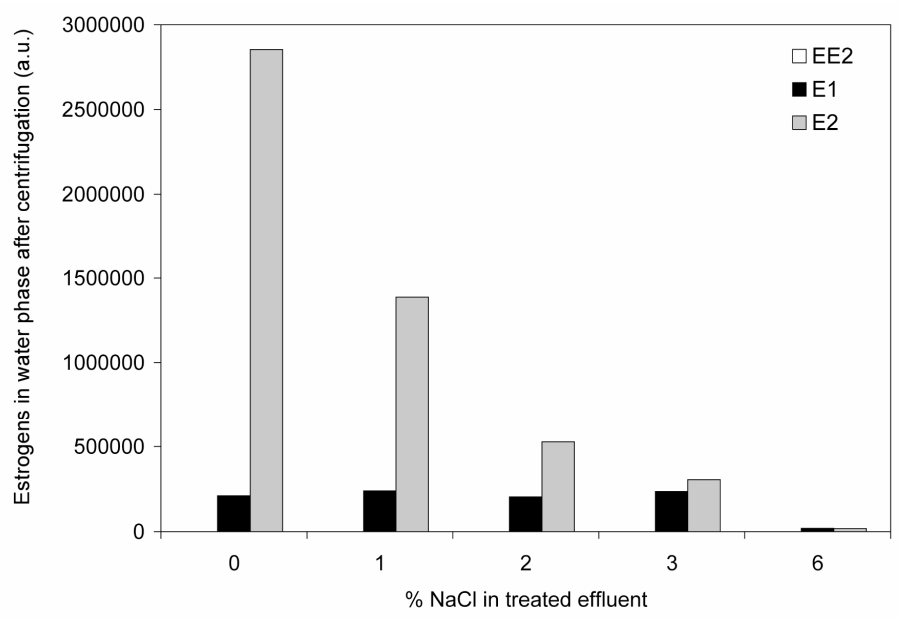

\begin{tabular}{cccccc}
\hline Estrogen & $\begin{array}{c}\text { Mean } \\
\text { concentration in } \\
\text { treated effluent } \\
(\mathrm{ng} / \mathrm{L})^{\mathrm{a}}\end{array}$ & $\begin{array}{c}\text { Mean fraction } \\
\text { adsorbed to } \\
\text { particles } \\
(\%)^{\mathrm{a}}\end{array}$ & $\begin{array}{c}\text { Estimated } \\
\text { concentration on } \\
\text { particulates }^{\mathrm{b}, \mathrm{c}}\end{array}$ & $\begin{array}{c}\text { Estimated } \\
\text { concentration } \\
\text { in surficial }\end{array}$ & $\begin{array}{c}\text { Measured } \\
\text { concentration } \\
\text { in surficial }\end{array}$ \\
& & & & $\begin{array}{c}\text { sediments } \\
(\mathrm{ng} / \mathrm{g})\end{array}$ & $\begin{array}{c}\text { sediments } \\
(\mathrm{n}=4)\end{array}$ \\
& & & & & $(\mathrm{ng} / \mathrm{g})$ \\
\hline E1 & 54 & 24 & 96 & 1.9 & $0.16-1.17$ \\
E2 & 14 & 43 & 45 & 0.9 & $0.22-2.48$ \\
EE2 & $<5$ & 100 & 19 & 0.4 & $<0.1-0.5$ \\
\hline a & & & & &
\end{tabular}

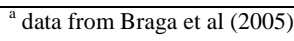

${ }^{\mathrm{b}}$ assuming suspended solids concentration is $135 \mathrm{mg} / \mathrm{L}$ (SWC, 2002)

${ }^{c}$ assuming EE2 concentration in treated effluent of $2.5 \mathrm{ng} / \mathrm{L}$

${ }^{\mathrm{d}}$ assuming sewage particles contribute $2 \%$ to the total surficial sediments (Matthai et al., 2002) 